\title{
The Impact of Lexicographical Work on Language Use: The Case of Shona Monolingual Dictionaries in Zimbabwe ${ }^{*}$
}

\author{
S. Nyota, Department of Curriculum Studies (shumirainyota2@yahoo.com) \\ and J. Mapara, Department of Languages, Literature and Music, \\ (jacomapara@yahoo.co.uk), \\ Masvingo State University, Masvingo, Zimbabwe
}

\begin{abstract}
This article examines the impact of current lexicographical work in Zimbabwe on some sectors of Shona language use, namely education, media, medicine and local government. It looks specifically at Shona monolingual lexicographical projects completed by the African Languages Research Institute (ALRI), successor to the African Languages Lexical Project (ALLEX). It analyses how users of Shona in these particular sectors are responding to the different lexicographical products published by ALRI. The article maintains that Shona monolingual lexicography has resulted in language raising and awareness. It has also led to term creation and has contributed towards standardisation of the language. Shona has furthermore gained the abstractive power it needs to explain its own and other concepts. All these have caused diglossia leakage from Low (L) Shona to High $(\mathrm{H})$ Shona in some areas of Shona language usage. The overall effect is that Shona is now used in some formal sectors such as the above-mentioned ones which previously were the preserve of English in Zimbabwe.
\end{abstract}

Keywords: MONOLINGUAL LEXICOGRAPHY, GENERAL DICTIONARIES, SPECIALISED DICTIONARIES, STANDARDISATION, LANGUAGE RAISING, LANGUAGE AWARENESS, LANGUAGE USE, SLCA, ALLEX, ALRI

Opsomming: Die invloed van leksikografiese werk op taalgebruik: Die geval van Sjona- eentalige woordeboeke in Zimbabwe. Hierdie artikel ondersoek die uitwerking van die huidige leksikografiese werk in Zimbabwe op sekere sektore van Sjonataalgebruik, naamlik opvoeding, media, geneeskunde en plaaslike regering. Dit kyk spesifiek na Sjonaeentalige leksikografiese projekte wat deur die African Languages Research Institute (ALRI), opvolger van die African Languages Lexical Projects (ALLEX), voltooi is. Dit ontleed hoe gebruikers van Sjona in hierdie besondere sektore reageer op die verskillende leksikografiese produkte wat ALRI gepubliseer het. Die artikel voer aan dat Sjona- eentalige leksikografie taalverhoging en

* This article was presented as a paper at the Eleventh International Conference of the African Association for Lexicography organised by the Tshivenda National Lexicographic Unit, University of Venda for Science and Technology, Thohoyandou, Republic of South Africa, 3-7 July 2006.

Submitted for Lexikos 17 (AFRILEX-reeks/series 17: 2007): 385-396 
-bewustheid tot gevolg gehad het. Dit het ook gelei tot termskepping en het bygedra tot die standaardisering van die taal. Sjona het verder die abstraherende vermoë verkry wat dit nodig het om sy eie en ander konsepte te verduidelik. Dit alles het diglossielekkasie van Lae (L) Sjona na Hoë $(\mathrm{H})$ Sjona op sekere gebiede van Sjonataalgebruik veroorsaak. Die algehele uitwerking is dat Sjona tans gebruik word in 'n aantal formele sektore soos die bogenoemdes wat vroeër die alleengebied van Engels in Zimbabwe was.

Sleutelwoorde: EENTALIGE LEKSIKOGRAFIE, ALGEMENE WOORDEBOEKE, GESPESIALISEERDE WOORDEBOEKE, STANDAARDISERING, TAALVERHOGING, TAALBEWUSTHEID, TAALGEBRUIK, SLCA, ALLEX, ALRI

\section{Introduction}

In addition to compiling dictionaries, the African Languages Research Institute (ALRI) also carries out language research and documentation and for this it has full-time data entry operators. However, this article deals exclusively with ALRI's lexicographical work in Shona. From its inception in 1992, the African Languages Lexical (ALLEX) Project, now ALRI, has published six Shona and Ndebele monolingual dictionaries. The Shona dictionaries are Duramazwi reChiShona (Shona Dictionary) (1996), Duramazwi Guru reChiShona (Advanced Shona Dictionary) (2001) Duramazwi reUrapi neUtano (Dictionary of Shona Biomedical Terms) (2004) and Duramazwi reMimhanzi (Dictionary of Shona Musical Terms) (2005). For the largest part, the information in these publications is in Shona, but there are English glossaries. The publications in Ndebele are: Isichazamazwi SesiNdebele (Ndebele Dictionary) (2001) and Isichazamazwi SezoMculo (Dictionary of Ndebele Musical Terms) (2006). The following are ALRI's forthcoming Shona dictionaries: Duramazwi reDudziramutauro neUvaranomwe (Dictionary of Shona Linguistic and Literary Terms) and Duramazwi reVana (Shona Children's Dictionary).

In a public lecture delivered as part of the University of Zimbabwe's Golden Jubilee Celebrations, Chimhundu (2005a) assesses the impact of lexicography on the raising of the languages in Zimbabwe with particular reference to Shona. His conclusions are that lexicography has had a tremendous impact on the raising of Shona as language. This article assesses the impact of monolingual lexicographical work on Shona language use. Monolingual lexicography is undoubtedly yielding positive results as far as the use of Shona is concerned.

Language use refers to all areas in which a language functions. Normally a language is assigned duties through status planning which is a type of language policy. However, as noted by Chimhundu (1997), there is no language policy framework in Zimbabwe (Roy-Campbell and Gwete 1997). The nearest Zimbabwe came to a language policy is through the 1987 Education Act Chapter 55 (Amended 1991; Part XI, paragraph 55: 225-226). This Act gives English official status while Shona and Ndebele are accorded national status. It rein- 
forces the diglossic relationship that exists between Shona and English in Zimbabwe. The term diglossia was first coined by Ferguson (1959) to describe language situations where a society employs two varieties of the same language "sufficiently distinct for lay people to call them separate languages" (Hudson 1996: 49). Ferguson calls these varieties H(igh) and L(ow). In a diglossic situation, they are used in a subset of mutually exclusive functions (Ferguson 1959, Fishman 1972). On the one hand, the high variety is associated with the superior functions of language namely parliament, news, announcements and other forms of journalistic writing, editorials in newspapers, academic, intellectual and formal discourse, court, legislative bodies, invitation cards, notices and advertisements. On the other hand, the low variety is used in such informal contexts as conversation at home, folk entertainment, addressing people at political gatherings, especially in the rural areas, and during parliamentary, senate and presidential elections, and instructions to workers in low prestige jobs.

The notion of diglossia as formulated by Ferguson was not extended to bilingual communities. His four case studies namely Egypt, Greece, Haiti and Switzerland concerned monolingual situations. Fishman (1972) proposed that Ferguson's 1959 model of diglossia be extended to bilingual situations. Whereas Ferguson (1959) is concerned with language varieties, Fishman (1972) relaxes this restriction and applies the concept diglossia to communities where two or more languages occur side by side. Fishman's (1972: 92) distinction of varieties is "along the lines of $\mathrm{H}(\mathrm{igh})$ languages on the one hand and $\mathrm{L}(\mathrm{ow})$ languages on the other". This is a reasonable extension of diglossia, especially in communities such as the one in which Shona found itself in the old Rhodesia where the colonial power enforced its own language as the language for formal purposes, thereby reducing the status of the indigenous languages. Styled along Fishman's (1972) notion of diglossia, this relationship in Zimbabwe is such that English has enjoyed high status $(\mathrm{H})$, while Shona (together with Ndebele) remains at low status (L) (Chimhundu 2006, Veit-Wild 2006, Mashiri 2002).

ALRI's Shona monolingual lexicographical work is therefore taking place in a diglossic situation where there is no clear language policy, where there is not a linguistic normative body (Chimhundu 2006: 11), and where the Education Act serving as language policy relegates the Shona language. Despite this uneven situation, standardisation of the Shona language is taking place, as Chimhundu (2006) confirms when he states:

The standardisation of the nominal national languages is happening without official policy planning or policy framework.

\section{Historical overview of lexicography and standardisation of Shona}

Lexicography is one of the pointers to standardisation of a language. The others are orthography and grammar. When Doke (1931) worked on the codification of the Shona language, he recommended the preparation of a comprehensive 
grammar and the compilation of dictionaries as a guide to literary work. Doke believed that carrying out such recommendations and implementing them would ultimately result "in the development of Shona as a great literary language" (cited in Chimhundu 2005a: 29). To this end, Chimhundu (2005a: 1) elaborates:

Since lexicography is the meeting point of all the disciplines that have a bearing on language, success in raising the status of a language and in diversifying its functions to cope with development and modernisation largely depends on advances made in lexicography and terminology in that particular language.

In the case of Shona, ensuing from Doke's recommendations, three bilingual dictionaries followed his 1931 orthography. These are Barnes (1932), Biehler (1950) and Wild (1953). Several other bilingual dictionaries and a grammar handbook were also produced after the revised orthography of 1955, for example, Hannan (1959, revised edition 1974), Dale (1975, revised edition 1981) and Fortune (1957, revised edition 1967). These developments in Shona lexicography coupled with developments in Shona orthography and grammar had an impact on the use of Shona. For instance, the first Shona novel, Feso by S.M. Mutswairo, was published in 1956, followed by B.T.G. Chidzero's Nzvengamutsvairo in 1957. The first poem was also written in 1956, H.W. Chitepo's epic Soko Risina Musoro (A Tale without a Head). The works of Fortune, Hannan and others impacted positively on the development of Shona fiction and poetry as well as the teaching of Shona as a subject and as a language. In the following years, other novels and poetry anthologies succeeded these first efforts by Mutswairo, Chidzero and Chitepo. Shona became examinable at Ordinary Level in 1958 and at Advanced Level in 1974 (Tsodzo 1992). However, these earlier developments in Shona grammar and lexicography were not immediately followed by an interest in the use of Shona in society in the same way as seems to be the case with the dictionaries resulting from Shona monolingual lexicographical work.

Recent developments in the field of Shona lexicography are those in which ALLEX/ALRI is involved, with a deliberate concentration on Shona monolingual dictionaries. Between 1992 and 1995, while work was being done on its first monolingual dictionary which was published in 1996, ALLEX carried out extensive research in all Shona-speaking areas in Zimbabwe. These research activities involved the grassroots, especially schools and colleges as well as university students with some of them participating as field research assistants. In this way, awareness of and improved attitudes towards Shona were created, boosting the participants' confidence in using Shona. The impact was great, because the publication of the first Shona monolingual dictionary was soon followed by the publication of grammar textbooks for Shona written in Shona. These are Mashiri and Warinda's "A" level textbook (1999) as well as Nyota's "O" level textbook (1999). At an "A" Level marking session in Harare in 2001 some markers who had been impressed not only by the work of Mashiri and Warinda (1999) and Nyota (1999), but also by Duramazwi reChiShona (1996) and 
Duramazwi Guru reChiShona (2001) mooted the idea of a Shona language association. This idea caught on and led to the formation of the Shona Language and Cultural Association (SLCA) at an initial meeting held at the Harare Girls' High School in 2002 and a subsequent meeting which took place at the Midlands State University in 2003. Today SLCA has become a strong partner of ALRI in Shona language research and documentation activities.

It is important to note that not only Mashiri and Warinda but also Nyota were motivated and aided by ALRI's monolingual dictionary of 1996. Their publications in turn made itself felt among teachers and students of Shona and other interested parties. In conjunction with SLCA, ALRI works tirelessly, carrying out campaigns to raise awareness of the part that Shona could play in Zimbabwe. ALRI and SLCA have regularly held joint meetings and have embarked on joint Shona projects such as an advanced analysis text of Shona literature ready for publication by Mambo Press. Other ongoing joint projects by ALRI and SLCA include a Shona phonetics and phonology text and a new and standardised Advanced Level Shona grammar text. There is reason to believe that the ALRI-SLCA campaigns are effective, because they involve Shona language users and promotors such as publishers, teachers from primary school to tertiary levels, the relevant Government ministries, the National Arts Council of Zimbabwe (NACZ), the Zimbabwe Schools Examination Council (ZIMSEC) and students. Consequently most people are now aware of the positive role Shona could play in its speech community. As a result of ALRI's monolingual dictionaries and the campaigns by both ALRI and SLCA, many areas such as the above-mentioned are increasingly using Shona where previously English was employed. Also following the ALRI-SLCA collaboration, positive responses have been noted as far as the use of Shona is concerned. For example, after the publication of Duramazwi reChiShona (1996) and Duramazwi Guru reChiShona (2001), some medical practitioners headed by Professor N.Z. Nyazema of the University of Zimbabwe's Medical School requested ALRI to produce a Shona medical dictionary. This resulted in the publication of the specialised Shona medical dictionary Duramazwi reUtano neUrapi (2004). This first dictionary of biomedical terms has in turn sparked the interest of more specialists and other practising medical personnel. A good example is Dr. F. Madzimbamuto, who has been motivated to join ALRI for the compilation of a larger and specialised biomedical dictionary. His contribution so far includes Muzongozo neHungunyo (The Vertebral Canal and its Contents) (2006) which gives such clear definitions that lay people can understand them, this in spite of the fact that Shona was once considered a language without terms relating to technical and scientific fields such as medicine. Even medical personnel themselves now see the need to simplify the medical jargon for the benefit of their patients, who are largely Shona-speaking and often elderly. This is a welcome development, because patients often comment on medical doctors' use of unfamiliar English words. As a result grown-up children have to accompany their elderly parents to doctors in order to translate the doctors' language and terminology for them. In sixteen pages that include diagrams showing parts of 
the vertebral canal and its contents, Madzimbamuto has succeeded in clarifying a body part that Mpofu et al. (2004: 41) originally defined in twenty-one words.

The impact of Shona monolingual lexicography cannot be overemphasised. Shona language communities have benefited greatly from this initiative of ALRI. Firstly, the dictionaries created the much-needed terminology in the teaching of Shona as a subject at different educational levels, that is, from grade one to tertiary levels. As noted earlier, this field is complemented by ALRI's prioritisation of and shift to specialised or terminological dictionaries in different domains of Shona language use, for example, medicine, language and literature, and music. This shows the practical approach of ALRI's research, as Chimhundu (2005a: 1) confirms when he says:

The primary motivation of the research programme has always been need filling. As a way of responding to the most urgent practical needs of the language communities ...

Secondly, the monolingual Shona dictionaries can also serve as a way of empowering the indigenous language communities in post-colonial Zimbabwe. The indigenous languages were downgraded during the colonial era, when English was prioritised. This was a time of strict diglossia with English as $\mathrm{H}$ and Shona as L. Monolingual dictionaries could be said to have effected a reversal of the diglossic relationship between Shona and English in some areas of language use in Zimbabwe, resulting in what Fasold (1984: 44) refers to as diglossia leakage. Fishman (1972) describes this occurrence as bilingualism without diglossia. This happens when a L(ow) language assumes the function formally reserved for the $\mathrm{H}$ (igh) language, as a result of the standardisation of the L language.

Chimhundu (2005a: 2) notes that monolingual lexicography has a particularly powerful impact during the language raising process:

The monolingual dictionary is not only standard setting, but it also gives a language the abstractive power that it needs to describe itself.

Following the ALRI-SLCA collaboration, there seems to be a growing interest in and general consciousness of the use of Shona in areas, which were originally dominated by English. Several other fields, including education, electronic and print media and national and local government, have also shown the same interest as noted in the domain of medicine.

\section{Areas showing the impact of lexicography}

\section{Education}

One area exhibiting a close link with Shona lexicography is that of education. Prior to the publication of monolingual Shona dictionaries, some elements of Shona language and literature were taught in English, the argument being that 
these were too complex for Shona to handle. Research by Dube (1995) on the diglossic relationship between English and Shona revealed that her respondents claimed English to be more expressive than Shona and Shona to lack grammatical, linguistic and literary terms. As such the respondents preferred English to Shona as medium of instruction for Shona grammar, linguistics and literature. These respondents may have revealed negative attitudes towards Shona, but their responses also indicated the underdevelopment of Shona. Shona then indeed lacked the technical terms for grammar, linguistics and literature as well as for other subject areas.

The result was that Shona grammar was taught in English, both at secondary and tertiary levels. For examination purposes at secondary school level, there was the choice of answering questions in either Shona or English. The Shona option was an empty formality because the technical terms for the language were all in English. Even examiners' marking schemes were in English. At that time, all teachers' colleges as well as the University of Zimbabwe (UZ) taught all Shona courses in English. This practice continued even after independence, especially at the UZ's Department of African Languages and Literature. This was despite the existence of the Education Act of 1987 (Amended 1991), Chapter 55, Number 3, which states:

From the fourth grade, English shall be the medium of instruction; provided that Shona or Ndebele shall be taught as subjects on an equal time allocation basis as the English language.

The situation seems to have changed with the publication of the Shona monolingual dictionaries compiled by ALRI, which inspired Mashiri and Warinda (1999) and Nyota (1999) to write Shona grammar textbooks in Shona. This was a result of the influence of the publication of the first monolingual dictionary as well as interest generated during the extensive data-gathering exercise carried out by ALLEX prior to its publication. Consequently, at secondary school level, Shona grammar, language and literature are now being taught and examined in Shona (Secretary's Circular Number 1 of 2002). The underdevelopment of Shona is no longer an issue in this domain since lexicographical work at ALRI has created and standardised the technical terms, the lack of which was an impediment. Even ZIMSEC is now working in close conjunction with ALRI in this regard.

Another pointer to the impact of Shona lexicography on education is the publication of grammatical works. After standardising Shona orthography, one of Doke's recommendations was, as noted earlier, the writing of a comprehensive grammar as a guide to Shona literary work. George Fortune is someone who followed this consignment. His works include An Analytical Grammar of Shona (1955), Elements of Shona (1957), and Shona Grammatical Constructions (in two parts, 1984 and 1985). Other works are those by Chigidi (1988) and Chakamba et al. (1987).

These grammarians analysed Shona grammatical constructions using Eng- 
lish. They confirmed Dube's (1995) findings that pupils and students of Shona grammar and linguistics believed the grammatical and linguistic concepts were too complex for Shona to handle.

However, following the publication of the first Shona monolingual dictionary, this belief and practice proved to be only a myth, because Shona grammatical terms were created and Shona was used to explain itself as shown in Mashiri and Warinda (Dudziramutauro reChiShona 'A' Level, 1999) and Nyota (Dudziramutauro reChiShona 'O' Level, 1999). Works on Shona orthography were also written in Shona. Among them are Magwa's Manyorerwo eChiShona (1999) and Chimhundu's Nhaka yaDoke (2005b). These developments point towards the growth and expansion of Shona. An author such as Chigidi (1988) has been asked by his publishers to rewrite the English section on Shona grammar in his book in Shona, ensuring that it is in accordance with the terms standardised by the Shona monolingual dictionary and the forthcoming dictionary of Shona linguistic and literary terms.

\section{The electronic and print media}

There is also evidence that Shona monolingual lexicography has had some effect on both the electronic and print media. Chimhundu (2006: 10) observes that in 1990 the percentage usage of the majority language, Shona, by the Zimbabwe Broadcasting Corporation (ZBC) was $55 \%$ on the African languages station, Radio Zimbabwe (then called Radio 2), $40 \%$ on the educational channel, National FM (then Radio 4), 1.5\% on the almost entirely music station, Power FM (then Radio 3), and 1\% on the general and predominantly English language station, Spot FM (then Radio 1). Around that time, television programmes in Shona and Ndebele were very few. Only 1.5\% of motion pictures was in Shona. The circulation of English language newspapers such as The Herald was much larger than that of the only indigenous language newspaper Kwayedza/Umthunywa, catering for both Shona and Ndebele.

The language composition in the print media has since changed greatly with the local languages Shona and Ndebele given much more space. The newspaper Kwayedza/Umthunywa has since been separated into two newspapers, namely Kwayedza (for Shona) and Umthunywa (for Ndebele). The requirement that all broadcasting on radio and television should have $75 \%$ local content contributed to a dramatic increase in airtime for local languages, particularly Shona and Ndebele. Chimhundu (2006: 11) noted the benefits of this shift as follows: improved attitudes towards indigenous languages, and a greater use of local languages in public life and in business, especially advertising. Participants now also join freely and confidently in radio and television programmes using local languages. The effect of the $75 \%$ local content policy on the use of indigenous languages on radio and television must be acknowledged, but the contribution of the ALRI-SLCA alliance's awareness campaigns and the standardisation of Shona, partly as a result of monolingual lexicogra- 
phy, should not be underestimated. Shona and Ndebele which are allocated much more space and time over the other indigenous languages are the most developed, with Shona having an edge over Ndebele even in airtime slots and standardisation. If the increase had nothing to do with the development of Shona, then the programmes would show many technical and terminological variations, inconsistencies and errors. However, this is not the case.

A common error is the use of the small letter " $\mathrm{v}$ " in the honorific prefix $\mathrm{Va}$ when it is used with people's names and surnames, e.g. vaChagumachii and vaTodyei instead of VaChagumachii and VaTodyei respectively. The error is caused by confusing the class 2 prefix $v a$ - which refers to number with $V a$ which is a form of address to show respect. It can be translated into English as "Mr" or "Mrs", depending on the gender of the addressee.

Word-division errors also occur frequently in Shona texts found in the media, for example in Shona advertisements in both the print and electronic media. Some advertisements on bill boards for Toyota Zimbabwe read Toyota $i$ mota ye vanhu instead of Toyota imota yevanhu (Toyota is the people's car). Another example is the Zimbabwian television soap serial called Tiriparwendo, which should be written Tiri parwendo (We are on a journey). These errors cannot be blamed on lexicography. Shona word-division problems can be backdated to the early missionaries who attempted to reproduce Shona in writing. The orthographies of the early missionaries who, from around 1900, embarked on writing unified Shona, were divergent in word-division, which were disjunctive, "guided mainly by equivalent translations in English and thus splitting Shona words unnecessarily" (cited in Chimhundu 2005c: 24). Doke (1931) recommended a conjunctive way of writing, which he considered appropriate for an agglutinative morphological typology such as that of Shona. This was a simple rule. However, the then Shona Language Committee made Shona worddivision rules much more elaborate and complex (Fortune 1972). This problem has persisted to this day as evidenced by the numerous word-division errors even in official documents. Dube (1995) who examined the problem concluded that it continues to exist, because, firstly, the rules are not taught at school and, secondly, they are too many and too difficult to commit to memory.

The other area, which shows an increased interest in using Shona, is that of advertising. In a strict diglossic situation, as noted earlier, advertising is the preserve of the $\mathrm{H}$ language or language variety. This situation used to prevail in Zimbabwe. Pongweni (1983), who analysed the language of advertising used only one Shona advertisement, as compared to the numerous English ones. Mutangadura (2001) had two Shona advertisements against five in English. The situation has now changed. The media, both print and electronic, is inundated with Shona advertisements, as can be seen when reading newspapers, watching television, listening to the radio or passing billboards. The impact of ALRI's work on the media is the result of the campaigns embarked on by the SLCA, which, in the days prior to its launch, invited all stakeholders, including those from the Ministry of Information. 
Both the indigenous and multinational corporations show an increased interest in Shona advertisements. Social service providers and political propagandists also use Shona advertisements. Agricultural, communication, insurance and construction companies are some of the sectors that have numerous and effective Shona advertisements. An analysis of the advertisements shows that they attract attention. They arouse interest, stimulate desire and create conviction, drawing positive responses and reactions from their audiences. In other words, apart from the word-division problem, Shona advertisements compete favourably with those in English. The impact of these advertisements relies on the standardised terminology found in the monolingual dictionaries. This has helped them to reach out to the bulk of the population, since Shonas constitute more than $75 \%$ of Zimbabweans.

\section{National and local governments}

The other impact of monolingual dictionaries is noticeable from the way some local municipality councils now communicate with residents by distributing their notices and circulars in Shona. An example is the municipality of Masvingo that informs residents in Shona about issues relating to water use and sewerage pipes. The city of Harare also warns residents in Shona not to amass and dump rubbish in certain areas. The way the notices and circulars are composed clearly shows that the writers have benefited from the orthography and terminology resulting from ALRI/ALLEX. This becomes evident from the minimum errors these now contain, unlike in the past when mistakes were a common feature of the few notices and circulars that were distributed in Shona.

While the lexicographical work undertaken by ALRI has had a major impact on these critical sectors of Zimbabwean society, there are some areas where the use of Shona, despite its development as a standardised language, is being resisted. Some denominations and especially the courts are examples. Like these denominations, the courts rely on translators, even where the plaintiff, the defendant, the prosecutor and the judge or magistrate are Shonaspeaking. Hopefully the courts will also realise the importance of empowering those who attend the courts for various reasons. This can be done through the use of the language they are most comfortable with and understand best.

\section{Conclusion}

This article has shown that monolingual lexicography has had a great and positive impact on Shona-speaking communities in Zimbabwe. Its influence has been realised in areas like the media, education, medicine and local government. Initially lexicography has aided in the standardisation of the Shona language. Then this has made the extension of the use of Shona possible in areas previously the reserve of English only. This in turn has empowered the Shona-speaking communities who can now use the language they understand 
and identify with. What it means is that the majority of the people can now participate in developmental issues without being excluded, because of language.

\section{Bibliography}

Barnes, E.W. 1932. A Vocabulary of the Dialects of Mashonaland in the New Orthography. London: The Sheldon Press.

Biehler, E. 1950. A Shona Dictionary with An Outline of Shona Grammar. Revised edition. Chishawasha/Salisbury: The Jesuit Fathers / Cape Town: Longmans, Green.

Chakamba, R. et al. 1987. Jekesa Pfungwa 3. Harare: Longman.

Chigidi, W.L. 1988. Focus Study Aids: A Level Shona. Harare: College Press.

Chimhundu, H. 1997. Language Standardisation without Policy or Planning: Zimbabwe as a Case Study. Røyneland, V. (Ed.). 1997. Language Contact and Language Conflict: 129-150. Volda: Volda College.

Chimhundu, H. 2005a. Lexicography and Language Raising: Dictionaries in Zimbabwean Languages. Public lecture presented as part of the Golden Jubilee Celebrations of the University of Zimbabwe, Harare, 13 April 2005.

Chimhundu, H. 2005b. Nhaka yaDoke. Harare/Oslo: ALLEX Project/Department of Linguistics and Nordic Studies.

Chimhundu, H. 2005c. Doke and the Development of Standard Shona. Introduction to a photographic reprint of Doke, C.M. 1931. Harare/Oslo: ALLEX Project and Unipub AS.

Chimhundu, H. 2006. Languages and Cultures of Marginalized Groups: Challenges of Inclusion in Higher Education. Paper presented at the International Conference on the Transformation of Masvingo State University to Great Zimbabwe National University, Great Zimbabwe Hotel, 17 19 January 2006.

Chimhundu, H. (Ed.). 1996. Duramazwi reChiShona. Harare: College Press.

Chimhundu, H. (Ed.). 2001. Duramazwi Guru reChiShona. Harare: College Press.

Dale, D. 1975. A Basic English-Shona Dictionary. Gwelo: Mambo Press.

Dale, D. 1981. Duramazwi: A Basic Shona-English Dictionary. Gwelo: Mambo Press.

Doke, C.M. 1931. Report on the Unification of Shona Dialects Carried Out under the Auspices of the Government of Southern Rhodesia and the Carnegie Corporation. Hertford: Stephen Austin.

Dube, S. 1995. A Study into the Reasons for the Diglossic Relationship between Shona and English in Postindependent Zimbabwe. Unpublished B.A. Honours Thesis. Pretoria: University of South Africa.

Fasold, R. 1984. The Sociolinguistics of Language. Oxford: Basil Blackwell.

Ferguson, C. 1959. Diglossia. Giglioli, P. (Ed.). 1972. Language and Social Context: Selected Readings: 232-251. Harmondsworth: Penguin Education.

Fishman, J.A. 1972. Language in Sociocultural Change. Stanford: Stanford University Press.

Fortune, G. 1955. An Analytical Grammar of Shona. London: Longmans, Green.

Fortune, G. 1957. Elements of Shona. London: Longmans, Green.

Fortune, G. 19672. Elements of Shona. Salisbury: Longmans.

Fortune, G. 1972. A Guide to Shona Spelling. Salisbury: Longmans.

Fortune, G. 1984. Shona Grammatical Constructions Volume 1. Harare: Mercury Press. 
Fortune, G. 1985. Shona Grammatical Constructions Volume 2. Harare: Mercury Press.

Government of Zimbabwe. 1987. The Education Act, Chapter 55. Harare: Government Printers.

Hadebe, S. (Ed.). 2001. Isichazamazwi SesiNdebele. Harare: College Press.

Hannan, M. 1959. Standard Shona Dictionary. Salisbury: The College Press.

Hannan, M. 1974. Standard Shona Dictionary. Second Edition. Salisbury: Rhodesia Literature Bureau.

Hudson, R.A. 1996. Sociolinguistics. Second edition. Cambridge: Cambridge University Press.

Madzimbamuto, F. 2006. Muzongozo neHungunyo (The Vertebral Canal and its Contents). Draft translation from Ellis, Harold, Stanley Feldman and William Harrop-Griffits. 2006. Anatomy for Anaesthetics. Eighth Edition. London: Blackwell.

Magwa, W. 1999. Manyorerwo eChiShona. Gweru: Mambo Press.

Mashiri, P. 2002. Shona-English Code-Mixing in the Speech of Students at the University of Zimbabwe. Southern African Linguistics and Applied Language Studies 20 (4): 245-262.

Mashiri, P. and C. Warinda. 1999. Dudziramutauro reChiShona " $A$ " Level. Gweru: Mambo Press.

Mheta, G. et al. (Eds.). 2005. Duramazwi reMimhanzi. Gweru: Mambo Press.

Mpofu, N. et al. (Eds.). 2004. Duramazwi reUrapi neUtano. Gweru: Mambo Press.

Mutangadura, J. 2001. The Language of Advertising: A Linguistic Approach to the Analysis of Advertisements. Unpublished M.A. Dissertation. Harare: University of Zimbabwe.

Nkomo, D. and N. Moyo (Eds.). 2006. Isichazamazwi SezoMculo. Gweru: Mambo Press.

Nyota, S. 1999. Dudziramutauro reChiShona "O" Level. Harare: Academic Books.

Pongweni, A.J.C. 1983. The Language of Advertising and its Social Cultural Implications for the Consumer. Issues in Development Seminar Series. Harare: University of Zimbabwe.

Roy-Campbell, Z.M. and W.B. Gwete. 1997. Language Policy and Planning (ECS 207). Harare: University of Zimbabwe, Centre for Distance Education

Tsodzo, T.K. 1992. Rurimi Rwaamai Book 3. Harare: College Press.

Veit-Wild, F. 2006. Zimbolicious - New Strategies for Verbal Exchange and Expressions in a Bilingual Cultural Setting: The Case of Zimbabwe. Unpublished paper presented at a public lecture at the University of Zimbabwe, 26 August.

Wild, H. 1953. A Southern Rhodesia Botanical Dictionary of Native and English Plant Names. Salisbury: Government Printers. 